\title{
Assessment of physiological indices and energetics under different system of rice intensification in north western Himalayas
}

\author{
Ranu Pathania $^{1 *}$, J. Shekhar ${ }^{1}$, S.S. Rana ${ }^{1}$ and Saurav Sharma ${ }^{2}$ \\ ${ }^{1}$ Department of Agronomy, Forages and Grassland Management, Chaudhary Sarwan Kumar Himachal Pradesh \\ Krishi Vishvavidyalaya, Palampur-176083 (Himachal Pradesh), INDIA \\ ${ }^{2}$ Chaudhary Charan Singh Haryana Agricultural University, Hisar (Hryana), INDIA \\ *Corresponding author. E-mail: ranu44raone@gmail.com
}

Received: March 11, 2017; Revised received: June 15, 2017; Accepted: October 30, 2017

\begin{abstract}
Field experiment was conducted at the research farm of CSK Himachal Pradesh Krishi Vishvavidyalaya, Rice and Wheat Research Centre, Malan during kharif 2013 with the objective to select the best seedling age and spacing of rice under system of rice intensification in terms of energetic and employment generation for mid hill condition of Himachal Pradesh. The experiment was laid out in 3 times replicated split plot design, assigning of three seedling ages (10, 17 and 24 days) and two spacings $(20 \mathrm{~cm} \times 20 \mathrm{~cm}$ and $20 \mathrm{~cm} \times 15 \mathrm{~cm})$ in main plots and four seedling vigours corresponding to four seeding rates $\left(25,30,35\right.$ and $\left.40 \mathrm{~g} / \mathrm{m}^{2}\right)$ in sub plots. The leaf area per plant was significantly greater in 10 days seedling age and decreased with increase in age $(P=0.05)$. Seedling rate did not affect leaf area index in all stages except 40 DAS when $35 \mathrm{~g} / \mathrm{m}^{2}$ seeding rate had maximum LAI. Seedling age did not significantly influence crop growth rate at any interval but it did relative growth rate and net assimilation rate between 40-70 and 70-100 DAS $(P=0.05) .24$ days old seedling resulted in significantly higher relative growth rate and net assimilation rate between 40-70 DAS followed by 17 days old seedlings. Maximum value of energy input (13.23) was recorded in 24 days seedling. The energy use efficiency (Energy output: input) varied from 10.6 to 11.1 under different treatments. Wider spacing supporting less plant population consumed 10 man days less than closer spacing of $20 \mathrm{~cm} \times 15 \mathrm{~cm}$.
\end{abstract}

Keywords: Energetics, Employment, SRI, Physiological Indices

\section{INTRODUCTION}

Agriculture is a continuous process of solar energy conversion into food, feed and fiber through photosynthesis. Old agriculture was based on scattering of seed on unprepared or occasionally prepared land in unplanned manner and accepting too little output that also if nature was kind enough. On the other hand, today's agriculture is well-planned application of energy to achieve desired results (Stout, 1990). Today the agriculture sector is one of the larger energyconsuming sectors, as agricultural production has many energy consuming operations such as tillage, intercultural, irrigation, application of fertilizers, agrochemicals for plant protection, harvesting, transportation etc. Mandal et al. (2002) reported that increase in mechanized level of operations for higher crop production increases the energy consumption.. Sufficient availability of the right energy and its effective and efficient use are prerequisites for improved agricultural production. Energy analysis, therefore, is necessary for efficient management of scarce resources for improved agricultural production. It would identify production practices that are economical and effective. Other benefits of energy analysis are to provide a basis for con- servation and to aid in making sound management and policy decisions.

Among the rice-growing countries India ranks first in area $(43.8 \mathrm{~m} \mathrm{ha})$ and second in production $(105.0 \mathrm{mt})$, next only to China. However, the average productivity of rice in India is only $3.44 \mathrm{t} /$ ha against the global average of $4.0 \mathrm{t} / \mathrm{ha}(\mathrm{FAO}, 2014)$. Rice is a semi aquatic plant and uses approximately 5000 liters of water to produce $1 \mathrm{~kg}$ of rice under puddle seeding condition and conventional methods of planting. Sustaining rice production under decreasing water availability and shrinking land area is becoming major challenge in mountain ecosystems. The possible way to increase the productivity of rice under organic management condition is through formulating better production technologies including the appropriate cultural practices along with high yielding rice genotypes. Avasthe et al. (2012) suggested that the system of rice intensification (SRI) holds a great promise in increasing the rice productivity. The productivity of a crop is related to the amount of growth attained and its partitioning into the different components especially the grain. Analysis of growth attributes provides an understanding of crop development and thereby the productivity. Keeping the above points in mind the present study was undertaken 
to analyse growth and energetics of SRI in relation to seeding date, spacing and seeding rate under mid hill conditions of Himachal Pradesh.

\section{MATERIALS AND METHODS}

Description of selected site: A field experiment was carried out during the kharif season of 2013 at the experimental farm of CSK Himachal Pradesh Krishi Vishvavidyalaya, Rice and Wheat Research Centre, Malan situated $\left(32^{0} 07^{\prime} \mathrm{N}\right.$ latitude, $76^{0} 23^{\prime} \mathrm{E}$ longitude and $950 \mathrm{~m}$ altitude) in North Western Himalayas. The soil of the experimental field was silty clay loam in texture and acidic in reaction. During rice crop season, mean weekly maximum temperature ranged between $26.6{ }^{\circ} \mathrm{C}$ in $43^{\text {rd }}$ standard week (22-28 October) and $34.7^{\circ} \mathrm{C}$ in $27^{\text {th }}$ standard week (2-8 July) during kharif 2013. Mean weekly minimum temperature ranged from $16.4{ }^{\circ} \mathrm{C}$ during $43^{\text {th }}$ standard week (29 October-4 November) to $22.1^{\circ} \mathrm{C}$ in $27^{\text {th }}$ standard week (2-8 July) during the year of experimentation. In kharif 2013, total rainfall of $2506.1 \mathrm{~mm}$ was received in 140 days. Mean weekly relative humidity ranged from $69 \%$ in October to $96 \%$ in August.

Experimental design: The field experiment was conducted in split plot design with three replications. The six combinations of three seedling ages (10, 17 and 24 days ) and two plant spacings $(20 \mathrm{~cm} \times 20 \mathrm{~cm}$ and 20 $\mathrm{cm} \times 15 \mathrm{~cm}$ ) were allocated to the main plots and seedlings of variable vigour obtained from various seeding rates $\left(25,30,35\right.$ and $\left.35 \mathrm{~g} / \mathrm{m}^{2}\right)$ in nursery to four sub plots. The normal seed (dry) of HPR 2612 a recommended scented rice variety treated with bavistin (400:1) was sown in rows $10 \mathrm{~cm}$ apart using preplanned seeding rates ( viz. 25,30,35 and $40 \mathrm{~g} / \mathrm{m}^{2}$ ) in distinct seed beds on $16^{\text {th }}$ June 2013. The seedlings were transplanted at three stages viz., $10\left(27^{\text {th }}\right.$ June 2013), 17 (4 $4^{\text {th }}$ July 2013) and $24\left(11^{\text {th }}\right.$ July 2013) days after planting at a spacing of $20 \mathrm{~cm} \times 20 \mathrm{~cm}$ and $20 \mathrm{~cm}$ $\mathrm{x} 15 \mathrm{~cm}$ as per treatment. The plots were regularly irrigated (as and when required) to keep the field moist throughout the crop season up to vegetative stage and water stagnation thereafter. For weed control butachlor $1.5 \mathrm{~kg} / \mathrm{ha}$ was used at 4 days after transplanting. After harvesting, threshing, cleaning and drying the grain yield was expressed at $14 \%$ moisture. Straw yield was obtained by subtracting grain yield from the total biomass yield. Yield was expressed in $t / h a$. The leaf area was calculated in accordance with the method described by Gomez (1972) as below:

Leaf area $=1 \times$ w x k

Where, 1 is the length, $w$ is the maximum width of the middle tiller in each hill and $\mathrm{k}$ is the adjustment factor. The value of $\mathrm{k}$ was 0.75 except at maturity for which the value was 0.67 . Accordingly,

Leaf area/hill $=$ total leaf area of middle tiller $\mathrm{x}$ total number of tillers; and

LAI $=$ Sum of leaf area/hill $\left(\mathrm{cm}^{2}\right) /$ area of land cov- ered/hill $\left(\mathrm{cm}^{2}\right)$

Crop growth rate (CGR), relative growth rate (RGR) and net assimilation rate (NAR) of the crop were calculated by the formulae outlined by Watson (1962) as below:

$$
\begin{aligned}
& \operatorname{CGR}\left(\mathrm{g} / \text { day } / \mathrm{m}^{2}\right)=\frac{\mathrm{W}_{2}-\mathrm{W}_{1}}{\mathrm{t}_{2}-\mathrm{t}_{1}} ; \\
& \operatorname{RGR}(\mathrm{g} / \mathrm{g} / \text { day })=\frac{\log _{\mathrm{e}} \mathrm{W}_{2}-\log _{\mathrm{p}} \mathrm{W}_{1}}{\mathrm{t}_{2}-\mathrm{t}_{1}} ; \text { and } \\
& \operatorname{NAR}\left(\mathrm{mg} / \text { day } / \mathrm{m}^{2}\right)=\frac{\log \in \mathrm{L}_{2}-\log \in \mathrm{L}_{1}}{\mathrm{t}_{2}-\mathrm{t}_{1}} X \frac{\mathrm{W}_{2}-\mathrm{W}_{1}}{\mathrm{~L}_{2}-\mathrm{L}_{1}}
\end{aligned}
$$

Where, $\mathrm{W}_{2}$ and $\mathrm{W}_{1}$ are the total dry weight and $\mathrm{L}_{2}$ and $L_{1}$ are leaf area at times $t_{2}$ and $t_{1}$, respectively.

Energetics of rice production: The input energy was worked out for different inputs used and operation carried out. The direct energy consists of diesel, human power and electricity, while the indirect energy contains seed, farmyard manure and machinery (Singh et al., 2007). The energy equivalent for different input and output are given in Table 1. Total physical output referred to sum of grain/seed and by-product yields. The output energy (MJ/ha) was obtained by multiplying the energy coefficient with grain and straw separately and then summing up these. Based on the energy equivalents of the inputs and output, energy indices were calculated as follow

Energy use efficiency = Gross energy output $(\mathrm{MJ} / \mathrm{ha}) /$ Energy input (MJ/ha)

Energy productivity $(\mathrm{kg} / \mathrm{MJ})=[$ Total output (grain+straw) (kg/ha)]/Total energy input (MJ/ha)

Net energy output $(\mathrm{MJ} / \mathrm{ha})=$ Gross energy output $(\mathrm{MJ} /$ ha) - Energy input (MJ/ha)

Energy intensity in physical terms $(\mathrm{MJ} / \mathrm{kg})=$ Total energy input $(\mathrm{MJ} / \mathrm{ha}) /$ Total output (grain+straw) $(\mathrm{kg} /$ ha)

Energy intensity in economic terms $(\mathrm{MJ} /)=$ Gross energy output (MJ/ha)/Cost of cultivation (INR/ha)

\section{RESULTS AND DISCUSSION}

\section{Physiological indices}

Leaf area index: The leaves of a plant are normally its main organ of photosynthesis and the total area of leaves per unit ground area, called leaf area index (LAI), has therefore been proposed by Watson (1947) as the best measure of the capacity of a crop producing dry matter and called it as productive capital. Leaf area index was worked out at 40, 70, 100 days and at maturity has been embodied in Table 2 . Leaf area and leaf area index increased gradually up to 70 DAS, and thereafter declined. It decreased towards maturity which may be due to lesser leaf number as a result of senescence in early formed leaves. The result obtained from the present study is consistent with the results of Sharma and Haloi (2001) who stated that variation in leaf area might be attributed to the difference in number of leaves. Seedling age significantly affected the 
Table 1. Energy equivalents for different inputs and outputs.

\begin{tabular}{|c|c|c|c|}
\hline Particulars & Units & Equivalent energy (MJ) & Remarks \\
\hline Man (adult) & Man-hour & 1.96 & - \\
\hline Diesel & Litre & 56.31 & Includes cost of lubrication \\
\hline \multicolumn{4}{|l|}{ Nutrient elements } \\
\hline a. Nitrogen & $\mathrm{kg}$ & 60.60 & Estimated quantity of $\mathrm{N}, \mathrm{P}_{2} \mathrm{O}_{5}$ and $\mathrm{K}_{2} \mathrm{O}$ in \\
\hline b. $\mathrm{P}_{2} \mathrm{O}_{5}$ & $\mathrm{~kg}$ & 11.10 & the fertilizer \\
\hline c. $\mathrm{K}_{2} \mathrm{O}$ & $\mathrm{kg}$ & 6.70 & \\
\hline Chemicals/pesticides & & & Chemicals requiring dilution at the time \\
\hline Agro -chemicals & $\mathrm{kg}$ & 120.00 & of application \\
\hline Rice grain & $\mathrm{kg}$ & 14.7 & - \\
\hline Rice straw & $\mathrm{kg}$ & 12.5 & - \\
\hline
\end{tabular}

Source: Mittal VK, Mittal JP and Dhawan KC. 1985. Research Digest on Energy Requirement in Agricultural Sector. Coordinating Cell AICRP (ERAS), College of Agricultural Engineering, PAU, Ludhiana.

leaf area index at 40 and 70 DAS. The leaf area index was significantly greater in 10 days seedling age and decreased with increase in age whereas 17 and 24 days old seedling age were at par with each other upto 70 DAS. At later stages, i.e. 100 DAS and at maturity stage leaf area index was statistically similar under all the seedling ages.

Spacing did not significantly influence leaf area index. But $20 \mathrm{~cm}$ x $15 \mathrm{~cm}$ spacing had an edge over $20 \mathrm{~cm} \mathrm{x}$ $20 \mathrm{~cm}$. Similar result was reported by Nayak et al. (2003) from Bhubaneswar where LAI was lower at wider spacing of $20 \mathrm{~cm} \times 15 \mathrm{~cm}$ compared to $15 \mathrm{~cm} \mathrm{x}$ $15 \mathrm{~cm}$ during wet season. Seedling rate did not affect leaf area index in all stages except 40 DAS when $35 \mathrm{~g}$ / $\mathrm{m}^{2}$ seeding rate had maximum LAI. The other treatments had equal LAI.

Growth parameters: Crop growth rate $\left(\mathrm{g} / \mathrm{m}^{2} /\right.$ day), Relative growth rate $(\mathrm{mg} / \mathrm{g} /$ day $)$ and net assimilation rate $\left(\mathrm{g} / \mathrm{m}^{2} /\right.$ day) were worked out between $40-70,70$ 100 DAS and 100 DAS- At maturity (Table 2). The RGR is a measure of dry matter accumulation/unit land area and per unit time. The RGR values showed a decreasing trend linearly up to harvest and a reduction at grain filling was due to the translocation of metabolites to the sink which is absolutely essential for better yield. The decline in RGR towards physiological maturity could be due to leaf shedding, shadow of upper leaves over the lower leaves which reduce the photosynthetic capacity of the lower leaves and finally loss of leaves due to pest attack (Banik et al., 2009). The crop growth rate during early growth period was slow; it increased sharply and reached its peak during maturity i.e. $19.7 \mathrm{~g} / \mathrm{m}^{2} /$ day. NAR had similar pattern as CGR. Rate of RGR declined with time and the corresponding minimum values were recorded as crop proceeded towards maturity. Similar result obtained by Jena et al (2010) where rate of RGR declined with time and the corresponding minimum value of $1.33 \mathrm{mg} / \mathrm{g} /$ day was recorded during 90 DAT -harvest. Seedling age did not significantly influence CGR at any interval but it did RGR and net assimilation rate between 40-70 and 70-100 DAS. 24 days old seedling resulted in significantly higher RGR and NAR between 40-70 DAS followed by 17 days old seedlings). CGR, RGR and NAR were not significantly influenced under the seeding rate in the nursery and spacing in the field.

Energetics: A perusal of the data (Table 3) revealed no significant effect of seedling age on grain yield of rice which varied in the range of $5245-5416 \mathrm{~kg} / \mathrm{ha}$. Nursery seeding rate also did not significantly influence the yield attributes and there by grain and straw yield of rice.

The data on effect of seedling age, plant spacing and seeding rate on energetic of rice production are presented in Table 3. Data revealed marked variation in energy input due to production factors. Maximum value of energy input $(13.31 \mathrm{GJ} / \mathrm{ha})$ was recorded in 10 days seedling. Different seedling ages, spacing and seeding rates did not induce variation in gross and net energy output, energy use efficiency, energy productivity, and energy intensity in physical and economic terms. The energy use efficiency (Energy output: input) varied from 10.6 to 11.1 under different treatments. The output energy was determined by the amount and quality of harvestable biomass (Gelfand et al., 2010). In the present investigation the different factors viz. crop spacing and seedling age did not have any influence significantly on rice energetics.

Employment: Old seedling, being easy to handle, consumed less man power compared to younger seedlings. Wider spacing supporting less plant population consumed 10 man days less than closer spacing of $20 \mathrm{~cm} \mathrm{x}$ $15 \mathrm{~cm}$. Similarly, using high seed rates for raising seedlings (thick nursery), requiring smaller nursery area consumed less manpower than lower seeding rates (thin nursery).

\section{Conclusion}

Seedling age, plant spacing and seeding rate did not have any influence on energetic but had little bit effect on generating the manpower. Younger seedling due to delicate nature and closer spacing required more man days. Thus the farmer' can practice any of these cultural practices of his choice keeping in cost and availability of labour in consideration. 
Ranu Pathania et al. / J. Appl. \& Nat. Sci. 9 (4): 2372 - 2376 (2017)
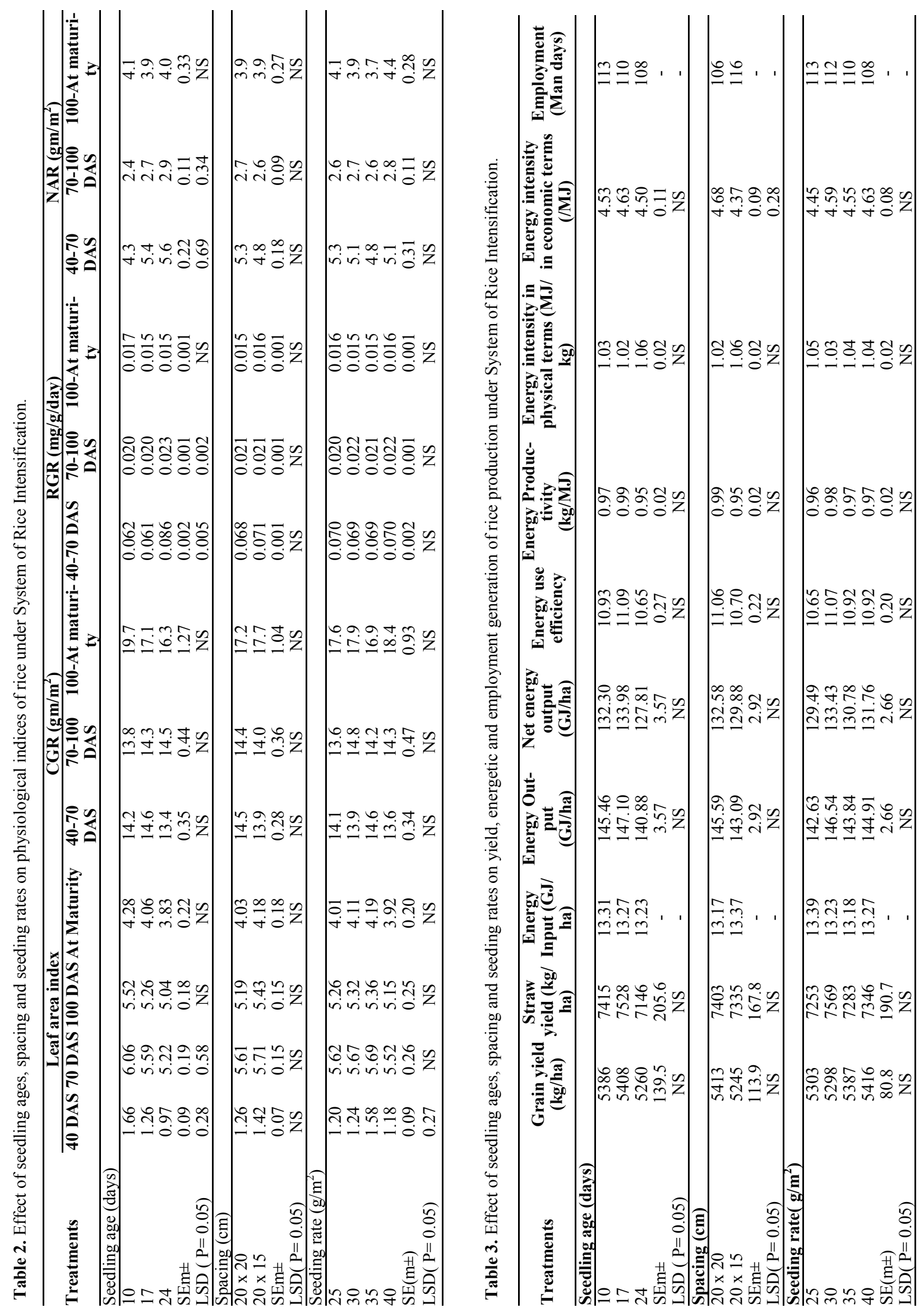


\section{REFERENCES}

Avasthe, R.K., Verma, S., Kumar, A. and Rahman, H. (2012). Performance of rice (Oryza sativa) varieties at different spacing under system of rice intensification (SRI) in mid hill acid soils of Sikkim Himalayas. Indian Journal of Agronomy 57(1): 32-37

Banik, C.N., Nath, R. and Chakraborty, P.K. 2009. Effect of dates of sowing on growth and yield of groundnut crop. Journal of Crop and Weed; 5(2):59-62.

FAO. (2014). FAO STAT Production Statistics, Food and Agriculture Organization, Rome, Italy

Gelfand, I., Snapp, S.S. and Robertson, G.P. (2010). Energy efficiency of conventional, organic and alternative cropping systems for food and fuel at a site in the U.S. Midwest. Environmental Science and Technology 44(10): 4,006-011

Gomez, K.A. (1972). Techniques for Field Experiments with Rice. International Rice Research Institute, Los Banos, Philippines.

Jena, S., Poonam, A.. and Nayak, B. C. (2010). Response of hybrid rice to time of planting and plant density. Oryza $47: 48-52$.
Mandal, K.G., K.P. Saha, P.K. Ghosh, K. Hati and M. Bandyopadhyay. (2002). Bioenergy and Economic analysis of Soybeanbased crop production system in central India. Biomass and Bioenergy. 23: 337-345

Nayak, A.R., Chaudhary, D., Reddy, J.N. (2003). Genetic variability and correlation study among quality characters in scented rice. Agriculture Science Digest 23(3): $175-178$

Sharma, S. K. and Haloi, B. (2001). Characterization of crop growth variable in some selected rice cultivars of Assam. Indian Journal of Plant Physiology, 6: 166 -171

Singh, V.P., Shankar, U. and Bora, P. (2007). Feasibility study to support system of rice intensification (SRI). http://dorabjitatatrust.org/Publications/pdf $\left[15^{\text {th }}\right.$ April, 2014]

Stout, B.A. (1990). Handbook of Energy for World Agric. Elsevier Applied Science. London

Watson, D.J. (1947). Comparative physiological studies on the growth of field crops I. Variation in net assimilation rate and leaf area between species and varieties within and between years. Annals of Botany, N. S. 11: 41-76

Watson, D.J. (1962). The physiological basis of variations in yield. Advances in Agronomy 4: 101-145 